\title{
Halobacillus karajensis sp. nov., a novel moderate halophile
}

\author{
M. A. Amoozegar, ${ }^{1}$ F. Malekzadeh, ${ }^{1}$ K. A. Malik, ${ }^{2}$ P. Schumann ${ }^{2}$ \\ and C. Spröer ${ }^{2}$ \\ ${ }^{1}$ Department of Biology (Microbiology Unit), Faculty of Science, University of Tehran, Tehran, Iran \\ ${ }^{2} \mathrm{DSMZ}$ - Deutsche Sammlung von Mikroorganismen und Zellkulturen GmbH, Mascheroder \\ Weg 1b, 38124 Braunschweig, Germany
}

Correspondence

F. Malekzadeh

falmero@yahoo.com

\begin{abstract}
A moderately halophilic, Gram-positive, spore-forming bacterium was isolated from surface saline soil of the Karaj region, Iran. The strain, designated $\mathrm{MA}-2^{\top}$, was strictly aerobic with rod-shaped cells that occurred singly, in pairs or short chains. It contained L-Orn-D-Asp-type peptidoglycan and the major respiratory lipoquinone was MK-7. It was non-motile and had an ellipsoidal endospore located centrally or subterminally. Growth occurred at $10-49^{\circ} \mathrm{C}$ and in the $\mathrm{pH}$ range $6 \cdot 0-9 \cdot 6$. Strain $\mathrm{MA}-2^{\top}$ grew at salinities of $1-24 \%(\mathrm{w} / \mathrm{v}) \mathrm{NaCl}$, showing optimal growth at $10 \%(\mathrm{w} / \mathrm{v})$. The DNA G $+\mathrm{C}$ content was $41 \cdot 3 \mathrm{~mol} \%$. Phylogenetic analysis based on 16S rRNA gene sequences showed that strain MA $-2^{\top}$ was associated with Bacillus rRNA group 1. The micro-organisms showing the closest phylogenetic relationship to strain MA-2 ${ }^{\top}$ were Halobacillus litoralis and Halobacillus trueperi. On the basis of phenotypic and chemotaxonomic characteristics, 16S rRNA gene sequence analysis and DNA-DNA similarity data, it is proposed that strain MA-2 ${ }^{\top}$ (=DSM $14948^{\top}=$ LMG $21515^{\top}$ ) should be placed in the genus Halobacillus as the type strain of a novel species, Halobacillus karajensis sp. nov.
\end{abstract}

Moderately halophilic bacteria include a heterogeneous group of micro-organisms consisting of different genera and species that grow in various salty environments (Ventosa et al., 1998). As described by Kaurichev (1980), soils containing more than $0.2 \%(\mathrm{w} / \mathrm{v})$ soluble salt are considered to be saline soils and such soils are scattered all over the world.

The microbiota of hypersaline soils are more similar to those of non-saline soils than the microbiota from hypersaline waters. This suggests that general features of the environment are more important in determining the microbiota in a particular habitat than are individual factors such as high salinity (Quesada et al., 1983). Moderately halophilic spore-forming bacteria, which are an important group, were formerly placed in the genus Bacillus (Claus \& Berkeley, 1986; Slepecky \& Hemphill, 1991), but now are placed in separate genera. The spore-forming moderate halophiles are found mostly in marine or hypersaline environments. Strain MA- $2^{\mathrm{T}}$ was isolated from moderately saline soil of the Karaj region, Iran, and its phenotypic and chemotaxonomic characteristics, cell wall composition, DNA $\mathrm{G}+\mathrm{C}$ content, DNA-DNA relatedness to other species and 16S rRNA gene sequences have been determined. The data obtained strongly support the suggestion

The EMBL accession number for the $16 \mathrm{~S}$ rDNA sequence of strain MA-2 ${ }^{\top}\left(=\mathrm{DSM} 14948^{\mathrm{T}}\right)$ is AJ486874. that this strain represents a novel species of the genus Halobacillus, and it has therefore been classified as Halobacillus karajensis sp. nov.

Soil samples were obtained from the geographical area of Karaj in Iran. The salinity of the samples was determined to be about $5 \%(\mathrm{w} / \mathrm{v}$, as total salt). Aliquots of the soil were added to a broth medium containing $\left(\mathrm{g} \mathrm{l}^{-1}\right)$ : $\mathrm{NaCl}, 81$; $\mathrm{MgCl}_{2} .6 \mathrm{H}_{2} \mathrm{O}, 7 ; \mathrm{MgSO}_{4} .7 \mathrm{H}_{2} \mathrm{O}, 9 \cdot 7 ; \mathrm{CaCl}_{2}, 0 \cdot 36 ; \mathrm{KCl}, 2$; $\mathrm{NaHCO}_{3}, 0 \cdot 06 ; \mathrm{NaBr}, 0.026$ (total salts, $100 \mathrm{~g} \mathrm{l}^{-1}$ ). The $\mathrm{pH}$ was adjusted to $7 \cdot 2-7 \cdot 4$ with $1 \mathrm{M} \mathrm{KOH}$ prior to autoclaving. Incubation was carried out at $34{ }^{\circ} \mathrm{C}$ under aerobic conditions. After a few days of incubation, agar plates were streaked, resulting mostly in white opaque colonies. Pure cultures were isolated after repeated re-streaking.

A pure culture of strain MA- $2^{\mathrm{T}}\left(=\mathrm{DSM} 14948^{\mathrm{T}}=\mathrm{LMG}\right.$ $21515^{\mathrm{T}}$ ) was grown and maintained in a complex medium containing $\left(\mathrm{g} \mathrm{l}^{-1}\right)$ : $\mathrm{NaCl}, 100 ; \mathrm{MgSO}_{4} .7 \mathrm{H}_{2} \mathrm{O}, 5$; casein peptone, 5; yeast extract, 3 (as recommended by Spring et al., 1996). A sporulation medium (Atlas, 1997) plus $5 \%$ $(\mathrm{w} / \mathrm{v}) \mathrm{NaCl}$ was used for sporulation. Incubation was carried out on a shaker at 150 r.p.m. and $34^{\circ} \mathrm{C}$. Morphological and physiological characteristics of the isolate were studied on nutrient agar or nutrient broth plus $10 \%$ (w/v) $\mathrm{NaCl}$. Reference strains Halobacillus trueperi DSM $10404^{\mathrm{T}}$, Halobacillus litoralis DSM $10405^{\mathrm{T}}$ and Halobacillus halophilus DSM $2266^{\mathrm{T}}$ were obtained from the DSMZ. 
SEM was used for morphological examinations. Strain MA- $2^{\mathrm{T}}$ was prepared for SEM according to the method of Bozzola \& Russell (1999) and specimens were observed on a Zeiss DSM 960 EM. Gram staining (Burke method) was performed and the result was confirmed by the $\mathrm{KOH}$ test (Baron \& Finegold, 1990). Motility was analysed by the wet-mount method (Murray et al., 1994). Catalase, oxidase and urease activity, nitrate reduction, hydrolysis of aesculin, methyl red, Voges-Proskauer and indole production were checked as recommended by Smibert \& Krieg (1994). Hydrolysis of Tween 80 was examined as described by Harrigan \& McCance (1976). Utilization of citrate and propionate was determined as recommended by Claus \& Berkeley (1986). Utilization of various carbohydrates and the production of acid were respectively determined as described by Atlas (1997) and Parry et al. (1988). All the above tests were performed using medium containing $10 \%$ $(\mathrm{w} / \mathrm{v}) \mathrm{NaCl}$.

Antibiotic sensitivity tests were performed on MuellerHinton agar plus $10 \%(\mathrm{w} / \mathrm{v}) \mathrm{NaCl}$ seeded with a bacterial suspension containing $1.5 \times 10^{6}$ c.f.u. $\mathrm{ml}^{-1}$ using discs (bioMérieux) impregnated with various antibiotics. The plates were incubated at $34^{\circ} \mathrm{C}$ for $48 \mathrm{~h}$ and the inhibition zone was interpreted according the manufacturer's manual. The specific growth rate $(\mu)$ was calculated as $0.693 \mathrm{~h}^{-1}$ using a spectroscopic method (Shimadzu model UV-160 A) at $620 \mathrm{~nm}$. Growth at various temperatures $(5,10,15,20$, $25,30,35,38,40,45,49,50$ and $55^{\circ} \mathrm{C}$ ) was determined. The $\mathrm{pH}$ range for growth was deduced and the final $\mathrm{pH}$ was adjusted to between 5 and 10 . At $\mathrm{pH}$ values greater than 6 , Tris buffer was used, and, at $\mathrm{pH}$ values below 6 , sodium acetate buffer was used. Other physiological and biochemical tests were performed as described previously (Quesada et al., 1984; Ventosa et al., 1982).

The interpeptide bridge in the cell-wall peptidoglycans was analysed using the method described by Schleifer \& Kandler (1972). Cell-wall hydrolysates were separated by one- or two-dimensional chromatography on cellulose thin-layer plates (Merck).

Fatty acid methyl esters were obtained from $40 \mathrm{mg}$ (wet wt) cells by saponification, methylation and extraction as described previously (Kämpfer \& Kroppenstedt, 1996; Kroppenstedt, 1985; Miller, 1982). The fatty acid methyl ester mixtures were separated by an automated GC system (model 5890 series II and 7673 autosampler; Agilent) controlled by MIS software (Microbial ID). Peaks were integrated automatically and fatty acid names and percentages were determined using the Microbial Identification standard software package (Sasser, 1990).

For determination of DNA base composition and DNADNA hybridization, DNA was isolated using a French pressure cell and purified by chromatography on hydroxyapatite as described by Cashion et al. (1977). The G+C content was determined by reversed-phase HPLC of nucleosides according to Mesbah et al. (1989). DNA-DNA hybridization studies were carried out according to the method of De Ley et al. (1970) with the modification described by Huß et al. (1983), using a Gilford System model 2600 spectrophotometer equipped with a Gilford model 2527-R thermoprogrammer and plotter. Renaturation rates were computed with the program TRANSFER.BAS (Jahnke, 1992).

Genomic DNA extraction, PCR-mediated amplification of the 16S rDNA, purification of PCR products and electrophoresis of sequencing products were done as described previously (Rainey et al., 1996). The $16 \mathrm{~S}$ rDNA sequence was aligned manually with published sequences from the Bacillus/Clostridium group contained in the DSMZ database of $16 \mathrm{~S}$ rDNA sequences. The ae2 editor (Maidak et al., 1999) was used to align the 16S rDNA sequences of strain MA- $2^{\mathrm{T}}$ against sequences of Halobacillus type strains available from public databases. Pairwise evolutionary distances were computed using the correction of Jukes \& Cantor (1969). The least-squares method (De Soete, 1983) was used to construct a phylogenetic dendrogram from distance matrices.

Cells of the isolate were rod-shaped $(0 \cdot 8-0 \cdot 9 \times 2 \cdot 5-$ $4 \cdot 0 \mu \mathrm{m})$, Gram-positive and strictly aerobic and occurred singly, in pairs or in short chains (Fig. 1). Under nonoptimal conditions for growth, particularly at $\mathrm{pH} 9 \cdot 0-9 \cdot 5$, a filamentous form appeared. The isolate was non-motile in media containing the various salt concentrations and $\mathrm{pH}$ values used in this study; this characteristic differentiated strain MA-2 ${ }^{\mathrm{T}}$ from all known Gram-positive, spore-forming, moderately halophilic bacteria (Arahal et al., 1999; Garabito et al., 1997; Spring et al., 1996; Schlesner et al., 2001; Ventosa et al., 1989). $\mathrm{MA}-2^{\mathrm{T}}$ formed ellipsoidal or spherical spores after growing on sporulation agar for 4 days. Spores were central or subterminal in position. Colonies were smooth, circular, white, entire, opaque and approx. $2 \mathrm{~mm}$ in diameter after 2 days at $34{ }^{\circ} \mathrm{C}$ on nutrient agar plus $10 \%(\mathrm{w} / \mathrm{v})$ $\mathrm{NaCl}$. Other characteristics that differentiate strain MA-2 ${ }^{\mathrm{T}}$

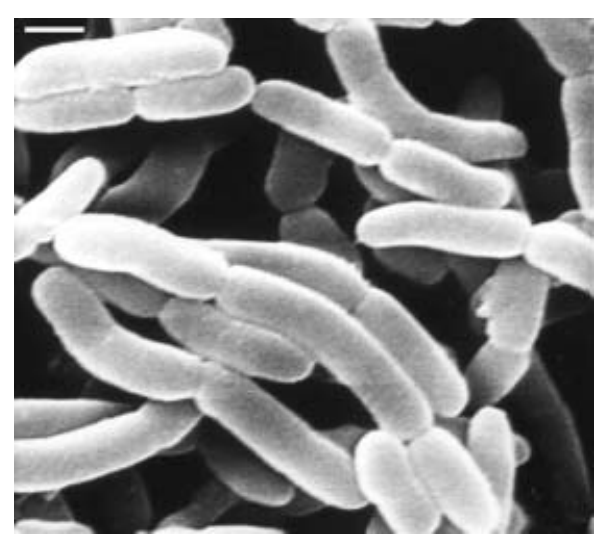

Fig. 1. Scanning electron micrograph of cells of Halobacillus karajensis sp. nov. MA-2 ${ }^{\top}$ from an exponentially growing culture. Bar, $1 \mu \mathrm{m}$. 
Table 1. Useful characteristics that distinguish Halobacillus karajensis sp. nov. from other related Gram-positive endosporeforming rods

Species: 1, H. karajensis sp. nov.; 2, H. halophilus; 3, H. litoralis; 4, H. trueperi; 5, Bacillus halophilus; 6, Salibacillus salexigens; 7, Salibacillus marismortui. Data from Arahal et al. (1999), Garabito et al. (1997), Spring et al. (1996), Ventosa et al. (1989) and this study. Abbreviations: E, ellipsoidal; s, spherical; C, central; ST, subterminal; T, terminal; $m$-Dpm, meso-diaminopimelic acid; ND, not determined.

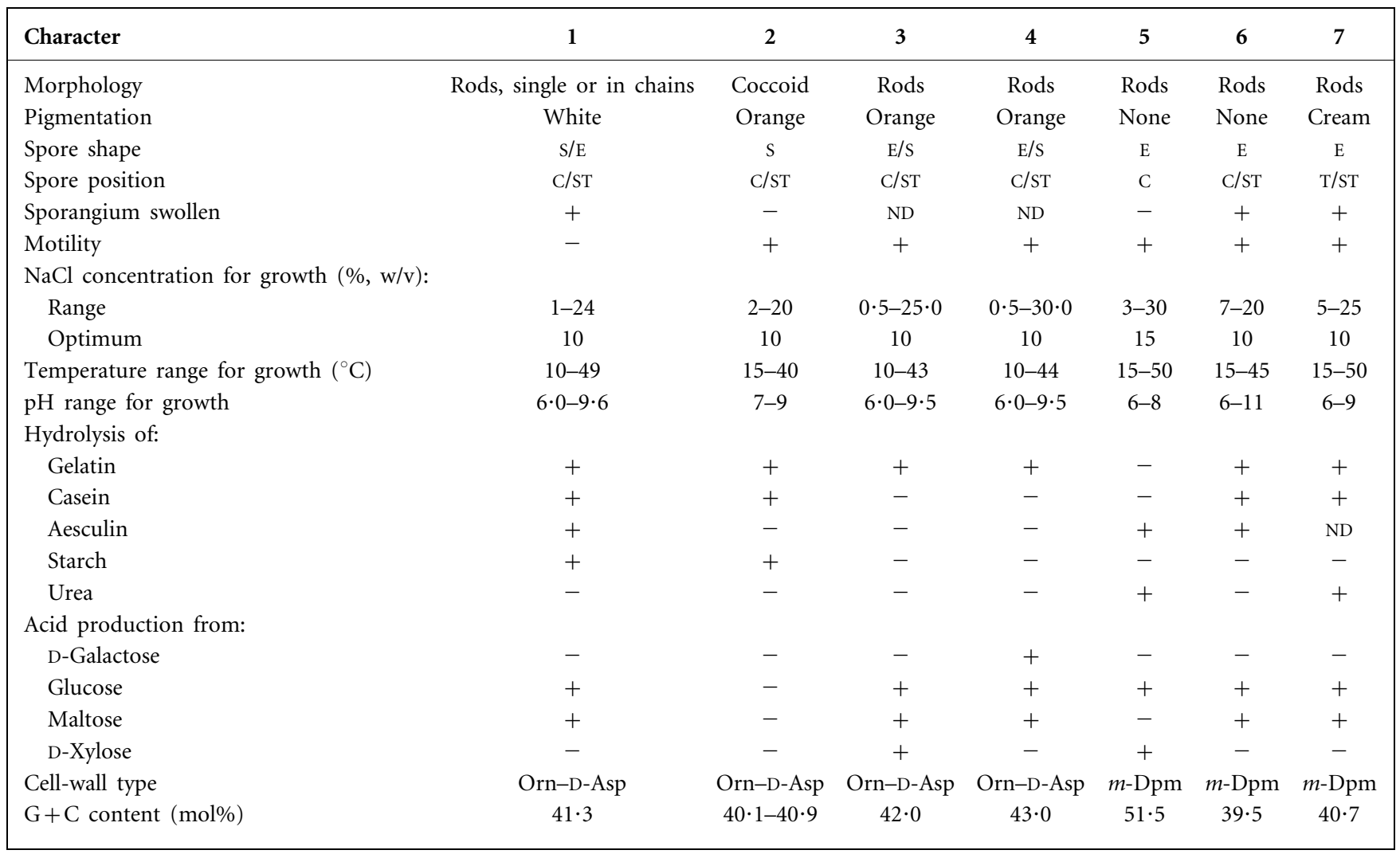

from related species are either shown in Table 1 or are included in the species description. MA- $2^{\mathrm{T}}$ did not contain diaminopimelic acid in the cell-wall peptidoglycan, but possessed Orn-D-Asp.

Whole-cell fatty acid compositions of various Halobacillus species are shown in Table 2. In general, the fatty acid patterns are very similar among species of this genus and differences are due mainly to varying quantities of some fatty acids. Branched fatty acids of the iso- and anteiso-types with chain lengths of 15:0,16:0 and 17:0 are clearly dominant, as observed in many other species of aerobic, spore-forming bacilli. In contrast, the abundance of the

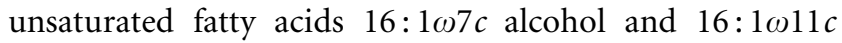
seems to be a characteristic of the genus Halobacillus.

The $\mathrm{G}+\mathrm{C}$ content of strain MA- $2^{\mathrm{T}}$ was $41 \cdot 3 \mathrm{~mol} \%$. DNADNA hybridization experiments revealed low levels of similarity between strain MA-2 ${ }^{\mathrm{T}}$ and $H$. trueperi DSM $10404^{\mathrm{T}}(32 \cdot 4 \%)$, H. litoralis DSM $10405^{\mathrm{T}}(22 \cdot 7 \%)$ and H. halophilus DSM $2266^{\mathrm{T}}(16 \cdot 9 \%)$.

The almost-complete $16 \mathrm{~S}$ rDNA sequence consisting of $1529 \mathrm{nt}$ was compared with sequences from members of the Bacillaceae. Members of the genus Halobacillus were the closest phylogenetic neighbours. Binary similarity values ranged from $99 \cdot 3 \%\left(H\right.$. litoralis DSM $10405^{\mathrm{T}}$, H. trueperi DSM $10404^{\mathrm{T}}$ ) to $97 \cdot 5 \%$ (H. halophilus NCIMB $2269^{\mathrm{T}}$ ). Similarly high values separated the type strains of $H$. litoralis and $H$. trueperi $(99 \cdot 5 \%)$. Phylogenetic trees were obtained using different distance-matrix-based clustering algorithms such as neighbour-joining and maximumlikelihood, as compiled in the PHYLIP package (Felsenstein, 1993). The different algorithms gave consistent results, placing strain $\mathrm{MA}-2^{\mathrm{T}}$ in a cluster together with $H$. litoralis and H. trueperi (Fig. 2).

Considering the phylogenetic, phenotypic and chemotaxonomic characteristics of the isolate, it is concluded that strain MA-2 ${ }^{\mathrm{T}}$ is part of rRNA group 1 of Bacillus (Ash et al., 1991) and belongs to the genus Halobacillus. The data presented in this paper indicate that strain $\mathrm{MA}-2^{\mathrm{T}}$ is somewhat related to $H$. trueperi. However, our strain exhibited differences from this and other known species of this genus. In contrast to the Halobacillus species described so far, strain $\mathrm{MA}-2^{\mathrm{T}}$ was non-motile. It formed white or cream-coloured colonies, whereas other species of the genus produce orange-pigmented colonies.

Strain MA-2 ${ }^{\mathrm{T}}$ grew well at $\mathrm{pH}$ 6・0-9·6, whereas H. halophilus 
Table 2. Cellular fatty acid composition of type strains of Halobacillus species

Strains: 1, H. halophilus DSM $2266^{\mathrm{T}} ; 2$, H. trueperi DSM $10404^{\mathrm{T}}$; 3, H. litoralis DSM $10405^{\mathrm{T}}$; 4, H. karajensis sp. nov. DSM $14948^{\mathrm{T}}$. Strains were grown on $\mathrm{MB}$ medium at $28^{\circ} \mathrm{C}$ for $48 \mathrm{~h}$ prior to analysis. Values are percentages of total fatty acids. The position of the double bond in unsaturated fatty acids is located by counting from the methyl $(\omega)$ end of the carbon chain; cis and trans isomers are respectively indicated by the suffixes $c$ and $t$. Summed features represent groups of two or three fatty acids that could not be separated by GLC with the MIDI system. Summed feature 4 contained one or more of iso-C17:1 I and/or anteiso-C17:1 B. ECL, Equivalent chain length; -, not detected.

\begin{tabular}{|c|c|c|c|c|c|}
\hline ECL & Fatty acid & 1 & 2 & 3 & 4 \\
\hline $13 \cdot 618$ & iso- $14: 0$ & $10 \cdot 6$ & $23 \cdot 2$ & - & $2 \cdot 0$ \\
\hline $14 \cdot 623$ & iso- $15: 0$ & $7 \cdot 4$ & $6 \cdot 6$ & $16 \cdot 3$ & $11 \cdot 3$ \\
\hline $14 \cdot 715$ & anteiso-15:0 & $42 \cdot 1$ & $19 \cdot 2$ & $45 \cdot 6$ & $42 \cdot 4$ \\
\hline $15 \cdot 000$ & $15: 0$ & $0 \cdot 8$ & - & - & $0 \cdot 3$ \\
\hline $15 \cdot 387$ & $16: 1 \omega 7 c$ alcohol & $8 \cdot 8$ & $12 \cdot 2$ & $2 \cdot 6$ & $9 \cdot 7$ \\
\hline $15 \cdot 627$ & iso- $16: 0$ & $14 \cdot 2$ & $28 \cdot 0$ & $1 \cdot 2$ & $6 \cdot 9$ \\
\hline $15 \cdot 756$ & $16: 1 \omega 11 c$ & $0 \cdot 6$ & $0 \cdot 7$ & $1 \cdot 3$ & $0 \cdot 9$ \\
\hline $15 \cdot 998$ & $16: 0$ & $1 \cdot 0$ & $1 \cdot 0$ & $0 \cdot 9$ & $1 \cdot 1$ \\
\hline $16 \cdot 388$ & iso- $17: 1 \omega 10 c$ & - & - & $2 \cdot 5$ & $1 \cdot 1$ \\
\hline $16 \cdot 478$ & Summed feature 4 & 0.9 & $1 \cdot 2$ & $6 \cdot 8$ & $3 \cdot 3$ \\
\hline $16 \cdot 631$ & iso- $17: 0$ & $1 \cdot 7$ & $2 \cdot 8$ & $7 \cdot 8$ & $5 \cdot 0$ \\
\hline $16 \cdot 724$ & anteiso-17:0 & $11 \cdot 6$ & $5 \cdot 1$ & $15 \cdot 0$ & $16 \cdot 0$ \\
\hline
\end{tabular}

does not grow below $\mathrm{pH} 7$ or above $\mathrm{pH}$ 9. It formed filaments at higher $\mathrm{pH}$ values $(9 \cdot 0-9 \cdot 5)$ and shorter and thicker bacillus cells at lower $\mathrm{pH}$ values. This is in contrast to the situation observed in $H$. litoralis and $H$. trueperi. In addition, strain $\mathrm{MA}-2^{\mathrm{T}}$ could hydrolyse aesculin; this also differentiated it from other known Halobacillus species.

In terms of growth temperature range, salt tolerance, enzymic activities and fermentation of sugars, there were differences between strain MA- $2^{\mathrm{T}}$ and other species of the genus (Table 1). On the basis of the evidence obtained from the phenotypic data, phylogenetic characteristics and DNA-DNA hybridization, it is proposed that strain MA- $2^{\mathrm{T}}$ be placed as the type strain in a novel species of the genus Halobacillus, Halobacillus karajensis sp. nov.

\section{Description of Halobacillus karajensis sp. nov.}

Halobacillus karajensis (ka.ra.jen'sis. N.L. masc. adj. karajensis from the region of Karaj, Iran, where the type strain was isolated).

Cells are Gram-positive rods, 2.5-4.0 $0 \cdot 8-0 \cdot 9 \mu \mathrm{m}$, occurring singly, in pairs or in short chains (Fig. 1). Non-motile, spherical or ellipsoidal endospores are produced in the central or subterminal position. Colonies are non-pigmented (cream or white), circular, opaque and entire. Growth occurs in $1-24 \%(\mathrm{w} / \mathrm{v}) \mathrm{NaCl} ; 10 \%(\mathrm{w} / \mathrm{v})$ is optimal for growth. No growth occurs in the absence of $\mathrm{NaCl}$. Growth

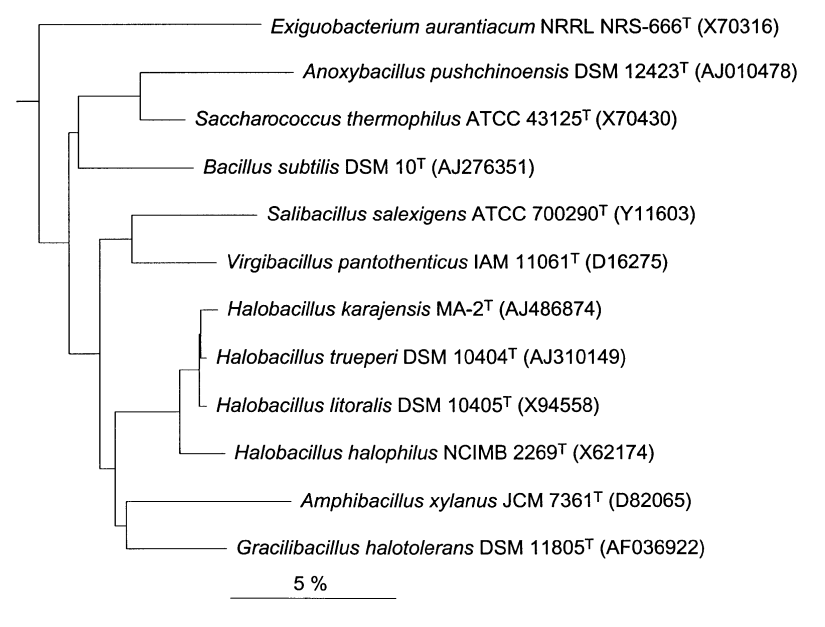

Fig. 2. Neighbour-joining tree showing the position of Halobacillus karajensis sp. nov. MA- $2^{\top}$ among type species of the family Bacillaceae. The sequence of Paenibacillus polymyxa DSM $36^{\top}$ served as an outside reference (not shown). Bar, 5 substitutions per $100 \mathrm{nt}$.

occurs at $10-49^{\circ} \mathrm{C}$ (optimum $34-38{ }^{\circ} \mathrm{C}$ ). The $\mathrm{pH}$ range for growth is $6 \cdot 0-9 \cdot 6$ (optimum between $7 \cdot 5$ and $8 \cdot 5$ ). Strictly aerobic. Catalase and oxidase are produced. Aesculin, casein, gelatin, starch and DNA are hydrolysed. Negative for hydrolysis of Tweens 80 and 20. Indole, methyl red, Voges-Proskauer and Simmons' citrate tests are negative. Urease is not produced. $\mathrm{H}_{2} \mathrm{~S}$ and phenylalanine deaminase are not produced. Acid is produced from D-glucose, D-fructose, maltose, mannitol, mannose and raffinose; D-arabinose, D-galactose, D-xylose and sucrose are not hydrolysed. The following compounds are utilized as sole carbon and energy sources: D-glucose, glucose 6-phosphate, D-cellobiose, starch, dextrin, maltose, D-melibiose, myoinositol, acetate, succinate and propionate. No growth occurs on D-sorbitol, inulin, salicin or citrate. Susceptible to ampicillin $(10 \mu \mathrm{g})$, amikacin $(30 \mu \mathrm{g})$, cephalotin $(30 \mu \mathrm{g})$, chloramphenicol $(30 \mu \mathrm{g})$, nalidixic acid $(30 \mu \mathrm{g})$, penicillin $\mathrm{G}(10 \mathrm{U})$, rifampicin $(5 \mu \mathrm{g})$ and tetracycline $(30 \mu \mathrm{g})$; resistant to erythromycin $(15 \mu \mathrm{g})$ and streptomycin $(10 \mu \mathrm{g})$; semi-susceptible to novobiocin $(5 \mu \mathrm{g})$. Other phenotypic features of this strain are shown in Table 1. The cell wall contains peptidoglycan of the Orn-Asp type. The major respiratory lipoquinone is MK-7.

The type strain, MA- $2^{\mathrm{T}}\left(=\right.$ DSM $\left.14948^{\mathrm{T}}=\mathrm{LMG} 21515^{\mathrm{T}}\right)$, was isolated from saline soil from Karaj, Iran. The $\mathrm{G}+\mathrm{C}$ content of the DNA of this strain is $41 \cdot 3 \mathrm{~mol} \%$.

\section{Acknowledgements}

We are grateful to Dr Reiner M. Kroppenstedt for providing comparative data on fatty acid composition and Dr Stefan Spring for critical discussions. This work was supported by the University of Tehran, grant 513/3/511. 


\section{References}

Arahal, D. R., Márquez, M. C., Volcani, B. E., Schleifer, K. H. \& Ventosa, A. (1999). Bacillus marismortui sp. nov., a new moderately halophilic species from the Dead Sea. Int J Syst Bacteriol 49, 521-530.

Ash, C., Farrow, J. A. E., Wallbanks, S. \& Collins, M. D. (1991). Phylogenetic heterogeneity of the genus Bacillus revealed by comparative analysis of small-subunit-ribosomal RNA sequences. Lett Appl Microbiol 13, 202-206.

Atlas, R. M. (1997). Handbook of Microbiological Media, 2nd edn. Boca Raton, FL: CRC press.

Baron, E. J. \& Finegold, S. M. (1990). Bailey and Scott's Diagnostic Microbiology, 8th edn. St Louis: Mosby.

Bozzola, J. J. \& Russell, M. S. (1999). Electron Microscopy: Principles and Techniques for Biologists, 2nd edn. Toronto: Jones \& Bartlett.

Cashion, P., Holder-Franklin, M. A., McCully, J. \& Franklin, M. (1977). A rapid method for the base ratio determination of bacterial DNA. Anal Biochem 81, 461-466.

Claus, D. \& Berkeley, R. C. W. (1986). Genus Bacillus Cohn 1872. In Bergey's Manual of Systematic Bacteriology, vol. 2, pp. 1105-1139. Edited by P. H. A. Sneath, N. S. Mair, M. E. Sharpe \& J. G. Holt. Baltimore: Williams \& Wilkins.

De Ley, J., Cattoir, H. \& Reynaerts, A. (1970). The quantitative measurement of DNA hybridization from renaturation rates. Eur J Biochem 12, 143-153.

De Soete, G. (1983). A least squares algorithm for fitting additive trees to proximity data. Psychometrika 48, 621-626.

Felsenstein, J. (1993). PHYLIP (phylogenetic inference package), version 3.5c. Department of Genetics, University of Washington, Seattle, WA, USA.

Garabito, M. J., Arahal, D. R., Mellado, E., Márquez, M. C. \& Ventosa, A. (1997). Bacillus salexigens sp. nov., a new moderately halophilic Bacillus species. Int J Syst Bacteriol 47, 735-741.

Harrigan, W. F. \& McCance, M. E. (1976). Laboratory Methods in Food and Dairy Microbiology. London: Academic Press.

Huß, V. A. R., Festl, H. \& Schleifer, K. H. (1983). Studies on the spectrophotometric determination of DNA hybridization from renaturation rates. Syst Appl Microbiol 4, 184-192.

Jahnke, K. D. (1992). Basic computer program for evaluation of spectroscopic DNA renaturation data from GILFORD System 2600 spectrometer on a PC/XT/AT type personal computer. J Microbiol Methods 15, 61-73.

Jukes, T. H. \& Cantor, C. R. (1969). Evolution of protein molecules. In Mammalian Protein Metabolism, vol. 3, pp. 21-132. Edited by H. N. Munro. New York: Academic Press.

Kämpfer, P. \& Kroppenstedt, R. M. (1996). Numerical analysis of fatty acid patterns of coryneform bacteria and related taxa. Can J Microbiol 42, 989-1005.

Kaurichev, I. S. (1980). Practicas de Edafologia. Moscow: Mir Publishers.

Kroppenstedt, R. M. (1985). Fatty acid and menaquinone analysis of actinomycetes and related organisms. In Chemical Methods in Bacterial Systematics, pp. 173-179. Edited by M. Goodfellow \& D. E. Minnikin. London: Academic Press.

Maidak, B. L., Cole, J. R., Parker, C. T., Jr \& 11 other authors (1999). A new version of the RDP (Ribosomal Database Project). Nucleic Acids Res 27, 171-173.
Mesbah, M., Premachandran, U. \& Whitman, W. B. (1989). Precise measurement of the $\mathrm{G}+\mathrm{C}$ content of deoxyribonucleic acid by high-performance liquid chromatography. Int J Syst Bacteriol 39, 159-167.

Miller, L. T. (1982). Single derivatization method for routine analysis of bacterial whole-cell fatty acid methyl esters, including hydroxy acids. J Clin Microbiol 16, 584-586.

Murray, R. G. E., Doetsch, R. N. \& Robinow, C. F. (1994). Determinative and cytological light microscopy. In Methods for General and Molecular Bacteriology, pp. 21-41. Edited by P. Gerhardt, R. G. E. Murray, W. A. Wood \& N. R. Krieg. Washington, DC: American Society for Microbiology.

Parry, J. M., Turnbull, P. C. B. \& Gibson, J. R. (1988). A Colour Atlas of Bacillus Species. London: Wolfe Medical Publications.

Quesada, E., Ventosa, A., Rodriguez-Valera, F., Megias, L. \& Ramos-Cormenzana, A. (1983). Numerical taxonomy of moderately halophilic Gram negative bacteria from hypersaline soils. J Gen Microbiol 129, 2649-2657.

Quesada, E., Ventosa, A., Ruiz-Berraquero, F. \& RamosCormenzana, A. (1984). Deleya halophila, a new species of moderately halophilic bacteria. Int J Syst Bacteriol 34, 287-292.

Rainey, F. A., Ward-Rainey, N., Kroppenstedt, R. M. \& Stackebrandt, E. (1996). The genus Nocardiopsis represents a phylogenetically coherent taxon and a distinct actinomycete lineage: proposal of Nocardiopsaceae fam. nov. Int J Syst Bacteriol 46, 1088-1092.

Sasser, M. (1990). Identification of bacteria by gas chromatography of cellular fatty acids. Technical Note 101. Newark, DE: MIDI.

Schleifer, K. H. \& Kandler, O. (1972). Peptidoglycan types of bacterial cell walls and their taxonomic implications. Bacteriol Rev 36, 407-477.

Schlesner, H., Lawson, P. A., Collins, M. D., Weiss, N., Wehmeyer, U., Völker, H. \& Thomm, M. (2001). Filobacillus milensis gen. nov., sp. nov., a new halophilic spore-forming bacterium with Orn-D-Glutype peptidoglycan. Int J Syst Evol Microbiol 51, 425-431.

Slepecky, R. A. \& Hemphill, H. E. (1991). The genus Bacillus - nonmedical. In The Prokaryotes, pp. 1663-1696. Edited by A. Balows, H. G. Trüper, M. Dworkin, W. Harder \& K. H. Schleifer. New York: Springer.

Smibert, R. M. \& Krieg, N. R. (1994). Phenotypic characterization. In Methods for General and Molecular Bacteriology, pp. 607-654. Edited by P. Gerhardt, R. G. E. Murray, W. A. Wood \& N. R. Krieg. Washington, DC: American Society for Microbiology.

Spring, S., Ludwig, W., Marquez, M. C., Ventosa, A. \& Schleifer, K. H. (1996). Halobacillus gen. nov., with descriptions of Halobacillus litoralis sp. nov. and Halobacillus trueperi sp. nov., and transfer of Sporosarcina halophila to Halobacillus halophilus comb. nov. Int J Syst Bacteriol 46, 492-496.

Ventosa, A., Quesada, E., Rodríguez-Valera, F., Ruiz-Berraquero, F. \& Ramos-Cormenzana, A. (1982). Numerical taxonomy of moderately halophilic Gram-negative rods. J Gen Microbiol 128, 1959-1968.

Ventosa, A., García, M. T., Kamekura, M., Onishi, H. \& RuizBerraquero, F. (1989). Bacillus halophilus sp. nov., a moderately halophilic Bacillus species. Syst Appl Microbiol 12, 162-166.

Ventosa, A., Nieto, J. J. \& Oren, A. (1998). Biology of moderately halophilic aerobic bacteria. Microbiol Mol Biol Rev 62, 504-544. 